\title{
'Zijn Vlamingen dan ook niet goed geïntegreerd?' Een kruispuntanalyse van integratievertogen in Vlaanderen vanuit het standpunt van moeders zonder papieren
}

\section{Tine Brouckaert}

TVGEND 17 (2): 131-147

DOI: 10.5117/TVGEND2014.2.BROU

\begin{abstract}
'Are Flemish people then also not well integrated?' An intersectional analysis of integration discourses in Flanders from the standpoint of undocumented, single mothers' is based on a longitudinal ethnographic study of ten undocumented migrant women who were residing in Flanders before and during the second regularisation period in 2009. This article deals with their confrontation with the regularisation criteria that were launched by the government in September 2009. From the point of view of single, undocumented mothers, the criterion of sustainable local anchoring relates to an ambivalent policy objective, which sometimes has contradictory outcomes. Authorities conceptualize integration largely through participation in networks, and in addition, networks are understood in a specific manner, which may disadvantage solidarity and in particular that in the lives of single, undocumented mothers. This article contrasts the way in which the authorities understand 'networks' to what participation in networks may mean to ten undocumented mothers, and indicates potential consequences of these different visions for social cohesion and social solidarity.
\end{abstract}

Keywords: integration, migrant women, minority politics, networks, single mothers, undocumented immigrants

Er zal altijd een verschil blijven, ook met papieren. Ook met een Belgische nationaliteit blijf je zwart. Studies en een goed werk kunnen je meer 'Belg' maken, alleen als je dat hebt, dan gaan de mensen van hier zeggen: 'Kijk, da's een Belg'. Maar als je de Belgische nationaliteit hebt en je bent een doorsnee iemand dan gaan ze zeggen: 'Het is een Afrikaan' en je telt niet mee. Alleen als je kan bereiken wat voor echte Belgen moeilijk te bereiken is dan pas ga 
je respect krijgen. Kijk naar Lukaku, iedereen is fier om te zeggen dat hij Belg is, maar als hij niet kon voetballen dan was hij niemand. ${ }^{1}$

Dit is een uitspraak van Ella ${ }^{2}$, een jonge vrouw uit Kameroen, gericht aan haar zoon. Voor Ella bestaat er geen twijfel over dat integratie de assimilatie betekent van minderheden aan een Vlaamse meerderheid in plaats van aan een bredere notie van wereldburgerschap. De beleidsmakers in Vlaanderen erkennen geen meervoudige identiteiten en deze blindheid creëert problematische en vaak onhoudbare situaties. In de praktijk geven de artificiële afbakeningen van een integratiebeleid dat op identiteit gestoeld is immers vaak aanleiding tot tegenstrijdige en perverse uitkomsten. Deze problematiek legt het wrikbaar evenwicht bloot tussen enerzijds het krampachtig vasthouden aan grenzen, en anderzijds het afbakenen van identiteiten in een postnationaal tijdperk waarin identiteiten meer dan ooit meervoudig en veranderlijk geworden zijn. Fort Europa kan gezien worden als een poging om deze dynamiek te beheersen, via de versoepeling van nationale grenzen die zich tegelijkertijd afspeelt met het verstrengen van de buitengrenzen van de EU.

Deze bijdrage is gebaseerd op een longitudinaal etnografisch onderzoek bij vrouwen die moeder zijn en zonder papieren verbleven in Vlaanderen tijdens de periode 2009 tot en met 2012. Het onderzoek liep net op het moment dat België een tweede grote regularisatiecampagne aankondigde in september 2009. Op basis van het vademecum dat de overheid toen verspreidde, werden de volgende criteria voor regularisatie opgesteld: (1) langdurige asielprocedures; (2) prangende humanitaire situaties; (3) gezinnen met schoolgaande kinderen waarvan de asielprocedure langer dan één jaar heeft geduurd en die sinds vijf jaar ononderbroken in België verblijven; en (4) duurzame lokale verankering. ${ }^{3}$

Dit artikel focust op het criterium 'duurzame lokale verankering', en bekijkt dit vanuit het perspectief van moeders zonder papieren. De participerende vrouwen aan dit onderzoek waren tien alleenstaande moeders die hun kinderen en zichzelf een betere toekomst wilden verzekeren, en daar dikwijls ook in geslaagd zijn. Bekeken vanuit hun standpunt verhoudt het criterium ‘duurzame lokale verankering' zich op een ambivalente en soms tegenstrijdige wijze tot de beleidsdoelstellingen die de overheid uitschreef tijdens de regularisatieperiode in 2009. De overheid conceptualiseert duurzame sociale en lokale verankering in grote mate via de participatie in netwerken, en bovendien worden netwerken op een specifieke wijze begrepen, zoals doorheen deze bijdrage duidelijk wordt. Dit artikel contrasteert de wijze waarop de overheid 'netwerken' begrijpt met hetgeen 
participatie binnen netwerken betekent vanuit het standpunt van moeders zonder papieren en geeft aan op welke punten deze verschillende visies op integratie gevolgen kunnen hebben voor de sociale cohesie en maatschappelijke solidariteit.

\section{Methodologie}

Deze studie is gebaseerd op een kleinschalige, longitudinale etnografische studie met tien vrouwen zonder papieren in Vlaams België. Het onderzoek liep van 2009 tot en met 2012, en de participerende vrouwen zijn uit diverse landen afkomstig: Bolivia, Peru, Marokko, Kameroen, Congo, Algerije en Iran. Ze verbleven tijdens de periode van het onderzoek in Gent en Antwerpen. De langste verblijfsduur in Vlaanderen bedroeg bijna 8 jaar, de kortste verblijfsduur nog geen maand. Alle vrouwen die aan het onderzoek deelnamen, waren moeders. De meesten onder hen werden moeder op Europees grondgebied. Enkelen kwamen met hun kinderen naar Europa, om zichzelf en hun kinderen een betere toekomst te bieden. De kinderen waren tussen de o en 17 jaar oud bij de aanvang van het onderzoek. Twee participanten hadden ook nog kinderen in het land van herkomst. Het aantal kinderen per vrouw ligt tussen één en vijf; een aantal dat in de loop van het onderzoek kon veranderen door nieuwe geboortes. De leeftijd van de moeders zelf lag tussen de 22 en 65 jaar. De moeders waren allen alleenstaand, maar bij sommigen veranderden hun relatiestatus tijdens de periode van het onderzoek. Geen van alle vrouwen was (nog) getrouwd. Vaders waren binnen dit onderzoek vooral tegenwoordig door hun afwezigheid. Naast de gedeelde kenmerken van moederschap en verblijf zonder papieren in Vlaanderen, verschilden de vrouwen aanzienlijk op het vlak van origine, klasse en religieuze achtergrond.

Ik ontmoette de vrouwen in eerste instantie via verschillende organisaties die werken voor en met vrouwen zonder papieren en breidde de respondentengroep vervolgens uit via een sneeuwbalsteekproef. Via etnografische participatie en semigestructureerde diepte-interviews werden gegevens verzameld over, en analyses gemaakt van, de verschillende levensdomeinen van deze vrouwen. Participerende observatie vond plaats bij dagelijkse activiteiten zoals het begeleiden van kinderen naar school, boodschappen doen, betaalde arbeid, vrienden bezoeken, feestjes, activiteiten buitenshuis, religieuze activiteiten en ook het meegaan naar sociale organisaties, sociaal werkers, advocaten, politie of rechtbank. Naast de dataverzameling met de informanten werden ook drie focusgroep-interviews georganiseerd om de 
verworven analyses te toetsen met een grotere groep vrouwen in dezelfde situatie (moeders zonder papieren). In dit artikel richt ik mij echter uitsluitend op de 10 sleutelfiguren die ik van nabij volgde (en die niet deelnamen aan de focusgroep-interviews) en focus ik op het begrip van integratie doorheen netwerken zoals dat gevalideerd werd in het kader van de regularisatiecampagne in 2009. Dit onderzoek beoogt niet representatief te zijn voor de totale populatie van vrouwen zonder papieren in Vlaanderen, maar wil wel aan de hand van een diepgaande analyse van de selecte groep en hun omgeving de confrontatie van de informanten met het integratiebegrip in Vlaanderen op een gedetailleerde wijze in kaart brengen. De illustraties uit de levensverhalen en praktijken van deze vrouwen moeten dus gelezen worden als unieke ervaringen, hoewel er gemeenschappelijke en structurele elementen kunnen opduiken. Theoretisch maakt dit onderzoek gebruik van het kritisch multiculturalisme (McDowell \& Fang Shi-Ruei, 2007) en het kruispuntdenken (Lykke, 2010). Kruispuntdenken, soms intersectioneel of caleidoscopisch denken genoemd, bekritiseert de eenzijdige categoriale benadering van gender of etniciteit (Botman et al. 2001). Het analyseert identiteiten of ervaringen vanuit het samenspel van sturende principes die spelen in elke maatschappij en die individuen en groepen een structureel voor- of nadeel kunnen verschaffen (Yuval-Davis, 2006). In het dagelijkse leven zijn identiteiten en ervaringen bijgevolg heel complex en altijd meervoudig. Bepaalde privileges (zoals witheid, heteroseksualiteit of burgerschap in Vlaanderen) zijn zo dominant aanwezig dat ze als norm fungeren en dat mensen met deze privileges moeilijk kunnen vatten dat de afwezigheid van deze privileges tot discriminatie kan leiden. Dergelijke positieblindheid en machtsverhoudingen die schuilen achter een ogenschijnlijk neutrale norm worden binnen het kruispuntdenken zichtbaar gemaakt.

\section{De relatieve waarde van netwerken}

Binnen onderzoek over netwerken in een migratiecontext worden netwerken meestal geconceptualiseerd in termen van solidariteit en wederzijdse afhankelijkheid gebaseerd op relaties van mensen met gedeelde waarden en normen. Doorgaans wordt daarbij spontaan gedacht dat familieleden of mensen van eenzelfde etnische gemeenschap en origine tot eenzelfde netwerk behoren (Boyd, 1989, p. 639). Veel beleidscriteria voor migranten en mensen zonder papieren worden gekoppeld aan deze hypothese. Dit onderzoek toont echter aan dat een dergelijke benadering van netwerken onhoudbaar is: het kruispuntdenken laat ons toe deze homogene visie op 
netwerken aan kritiek te onderwerpen, en andere aspecten van identiteit en ervaringen van mensen en groepen in rekening te brengen.

Vanuit het standpunt van de moeders zonder papieren die aan dit onderzoek deelnamen, kunnen de tegenstrijdigheden en dubbele standaarden in het beleidscriterium 'duurzame lokale verankering' zichtbaar worden gemaakt. Paquita ${ }^{4}$ was hierover bijzonder welbespraakt. Kort na de lancering van de regularisatiecampagne in september 2009 ging ik samen met Paquita langs bij haar advocaat om aanvullende stukken, die een langdurig verblijf en een geslaagde integratie in Vlaanderen moesten bewijzen, aan haar dossier toe te voegen. Zoals alle personen die hun verblijf willen regulariseren moest ook Paquita een reeks attesten voorleggen van personen die garant willen staan en getuigen van haar 'duurzame lokale verankering'. Een duurzame lokale verankering wordt hierbij als synoniem van een 'geslaagde integratie' opgevat. In deze context schreef ik getuigenissen voor verschillende personen en bevond ik mij dus in de positie om te oordelen over de al dan niet geslaagde integratie van personen zonder regulier burgerschapsstatuut. De reden dat ik dit kon, had ik blijkbaar niet enkel te danken aan mijn reguliere burgerschapsstatus, maar ook aan mijn Vlaams klinkende naam, zo werd duidelijk in het kantoor van Paquita's advocaat. Nadat hij haar eerst feliciteerde met het aantal attesten dat ze meebracht, volgde een moment van aarzeling en ten slotte zijn advies: 'Het merendeel van je getuigenissen komt van mensen uit de 'Latino'-gemeenschap; je dossier maakt meer kans op een positief antwoord als je ook van andere mensen een getuigenis toevoegt.' De personen die een getuigenis voor Paquita schreven, waren allen in het bezit van een reguliere burgerschapsstatus, maar hebben Spaans als moedertaal en zijn meestal afkomstig uit Zuid-Amerika. Die 'andere' mensen waar Paquita's advocaat op doelde, zijn dus Belgen niet enkel op basis van juridisch statuut maar ook op basis van naam en taal.

In de ogen van de beleidsmakers is het 'Latino-netwerk' een homogeen netwerk, terwijl Paquita's netwerk in Antwerpen mensen samenbrengt van verschillende nationaliteiten en uiteenlopende etniciteit, sociale klasse, religie, verblijfsduur in Vlaanderen en burgerschapstatuut. Deze vormen van diversiteit ondermijnen het idee van een homogeen netwerk, maar toch wordt dergelijke diversiteit niet au serieux genomen door de overheden en Paquita's advocaat wil hieraan tegemoetkomen en geeft advies dat moet verhinderen dat haar dossier als 'insolide' beschouwd wordt. Kortom, Paquita werd in het samenstellen van haar dossier geconfronteerd met de taal en de kleur van burgerschap. In principe is de overheid op zoek naar bridging capital dat de succesvolle lokale verankering en dus de integratie van mensen zonder papieren op een overtuigende wijze moet kunnen 
bewijzen. Bridging capital is sociaal kapitaal dat ontstaat door interacties en solidariteit tussen personen behorende tot verschillende groepen, met verschillende belangen. Het onderscheidt zich van bonding social capital, dat verwijst naar de netwerken tussen mensen van dezelfde homogene groep (Putnam, 200o). Maar in praktijk wordt duidelijk dat bridging capital op zich niet volstaat als indicatie van lokale verankering. Eens we het kabinet van de advocaat buitenkomen, vroeg Paquita me:

Vind jij dat logisch? [...] ik woon in Borgerhout, mijn vrienden die ik er in de voorbije jaren heb leren kennen, komen van alle hoeken van een continent groter dan Europa en mijn advocaat vindt dat ik niet goed geïntegreerd ben omdat mijn netwerk niet divers genoeg is?

En ze voegde eraan toe:'Zeg mij eens hoeveel Vlamingen één kennis hebben die van elders komen, laat staan een divers netwerk? Zij zijn dan ook niet goed geïntegreerd?' Paquita interpelleerde de dubbele standaard waardoor de diversiteit in haar netwerk, en in casu Borgerhout, niet gewaardeerd wordt. Zowel in de academische literatuur als in het integratiebeleid bij Europese liberale overheden (Fortier, 2010) blijft het idee van netwerken en gemeenschappen gebaseerd op homogene identiteiten voortbestaan. Devillé (2006, p. 143) spreekt in haar studie over mensen zonder papieren en hun netwerken in België van de zogenaamde outsider community, waarmee ze verwijst naar netwerken van sociale relaties die mensen zonder papieren opbouwen en die sterk op hun eigen gemeenschap gericht blijven, en dus op mensen van hetzelfde land van afkomst. Mensen die een sterke betrokkenheid en een reciprociteit onderhouden binnen deze netwerken, zo stelt Devillé, zijn minder goed geïntegreerd in de maatschappij van residentie dan degenen die niet kunnen rekenen op een breed sociaal netwerk. De term insider community gebruikt Devillé om netwerken aan te duiden van mensen die niet goed geïntegreerd zijn in een eigen gemeenschap: zij 'vereenzelvigen zich meer met 'Belgen' [...] en ontlenen hun identiteit zoals 'Belgen' meer aan de dominante samenleving' (2006, p. 2 - aanhalingstekens toegevoegd door auteur van dit artikel). Er bestaat in de literatuur onenigheid over de relatie tussen een engagement in deze netwerken en het minder goed of beter geïntegreerd zijn in de outsider community (Devillé, 2006, p. 143). Deze logica weerklinkt in het burgerschaps- en integratiemodel van liberale overheden, waarbinnen alleen banden met mensen uit de dominante posities geëvalueerd worden als potentiële vormen van burgerschap, en banden binnen gemeenschappen beschouwd worden als een gevaar voor de sociale cohesie en de nationale solidariteit. Hoewel sommigen ervan 
overtuigd zijn dat bonding capital op zijn beurt bijdraagt tot bridging capital, ligt de nadruk van het beleid in de evaluatie van mensen zonder papieren op hun bridging capital, hetgeen vervolgens selectief geïnterpreteerd wordt als relaties met de dominante gemeenschap.

Paquita stelde niet alleen de blindheid van de beleidsmakers aan de kaak die er niet in slagen om verschillende vormen van diversiteit en meervoudige identiteiten te erkennen, maar ook de asymmetrie waarop het overheidsmodel stoelt. Het Vlaamse beleid blijft integratie verstaan als de assimilatie van culturele minderheidsidentiteiten aan de identiteit van een Vlaamse meerderheid. Deze verwachting is gestoeld op een asymmetrische machtsrelatie. Zo vertelde Ella me:

Ik heb twee 'Belgische' vriendinnen, een vrouw uit het gesloten opvangcentrum die mij echt graag had en waarmee ik nu nog contact heb en jij. Contact met 'echte Vlamingen' is moeilijk voor ons. Niet omdat ik het niet wil, integendeel ik ben echt nieuwsgierig naar hun manier van leven. Soms observeer ik 'Belgische' vrouwen van mijn leeftijd en zie hoe zij nog meisjes zijn, zij hoeven zich geen zorgen te maken over het leven. [...] Soms zijn er 'Belgische' blanke mannen die op een opdringende manier contact met me proberen te leggen. Dat is me al twee keer overkomen, dan volgt hij me en blijft hij aandringen om te praten en dan weet ik dat ik niet de eerste Afrikaanse vrouw ben die deze man wil benaderen. Spontaan contact leggen is moeilijk en geloof me dat ik dat erg graag zou willen.

Integratie heeft in deze context weinig te maken met sociaal geslaagde interacties of verbondenheid met anderen, of met lokale verankering in een stad, maar meer met een door de meerderheid sociaal gewenste integratie. De overheid lijkt op zoek te zijn naar bridging capital als criterium voor sociale en affectieve verankering in Vlaanderen, maar het werd mijn informanten gaandeweg duidelijk dat de overheid niet op zoek is naar de 'brug' tussen mensen met en mensen zonder papieren, maar wel tussen de witte meerderheid en etnische minderheden. En passant worden de diverse netwerken van etnische minderheden als 'homogeen' gepositioneerd, en hun diversiteit effectief onzichtbaar gemaakt.

Het gevaar bestaat erin dat personen zonder papieren door deze assimilatiedruk hun informeel vangnet verliezen, hetgeen ook weer nefaste effecten heeft op de algemene sociale cohesie in de stad. De laatste decennia komt de solidariteit en sociale cohesie tussen mensen zonder papieren erg onder druk te staan, merkt het hoofd van een Antwerpse organisatie die werkt met mensen zonder papieren op: 
Zelfs voor gemeenschappen die heel erg op de groep zijn gericht is er geen evidentie meer. Als er bijvoorbeeld een hongerstaking of een kerkbezetting wordt gehouden dan bieden beleidsmakers een regularisatiemogelijkheid op basis van verblijfsduur of schoolgaande kinderen. Plots worden dit criteria voor integratie, maar door die willekeur verdwijnt de cohesie die binnen die groep bestond helemaal.

Nicholls, die onderzoek deed naar collectieve bewegingen van sans-papiers in Frankrijk, merkt op dat in een strijd voor erkenning personen strategisch gaan inspelen op de hiaten die het beleid laat tussen wettelijke vertogen van inclusie en exclusie (Nicholls, 2013), als gevolg daarvan ontstaat het risico dat de solidariteit en de cohesie van groepen ondermijnd wordt.

\section{Gegenderde solidariteit}

Hoewel de link tussen netwerken en zorgpraktijken algemeen wordt aangenomen (Stein, 1981; Portes, 2000; Leman, Siewiera \& Van Broeck, 1994; Leman, 1995; Engbersen, Van der Leun, Staring \& Kehla, 1999; Adam, Ben Mohammed, Kagné, Martiniello \& Rea, 2001; Devillé, 2006; Paspalanova, 2006; Brouckaert \& Longman, 2014), zijn er weinig gendergevoelige analyses over netwerken van migranten. Kritieken van feministen (met papieren) richten de aandacht op de uitsluiting van formele rechten en erkenning waarmee vrouwen structureel te maken hebben. ${ }^{5}$ Door een androcentrische opvatting van participatie bij politieke erkenning te laten domineren op de informele arbeid in zorgnetwerken, blijft de arbeid van vrouwen onzichtbaar of ondergewaardeerd. Daardoor worden opvoeden, zorg voor anderen of zorg voor essentiële randvoorwaarden om volwaardig burger te kunnen zijn, verbannen naar de onzichtbare, apolitieke privésfeer.

Ook vandaag blijven deze feministische kritieken legitiem: bij de regularisatiecriteria van 2009 worden duurzame lokale verankering of integratie expliciet gekoppeld aan de voorwaarde van een arbeidscontract of aan de duur van een verblijf in de natiestaat, en impliciet worden vooral relaties met personen behorende tot de meerderheid (een selectief begrip van bridging capital) politiek gewaardeerd. Een kruispuntperspectief maakt duidelijk hoe de uitsluiting en de discriminatie van vrouwen zonder papieren, sociaal en cultureel versterkt wordt. Paquita en de meeste andere vrouwen in dit onderzoek waren actief op de arbeidsmarkt en voerden onzichtbaar zorgwerk uit voor witte mannen en vrouwen met burgerschapsstatuut die meestal tot een twee-ouder-gezin behoren. Zo deed Paquita het huishouden van een 
advocate met man en kinderen in Antwerpen. Een deel van haar inkomsten stuurde ze naar haar moeder in Bolivia zodat deze kan instaan voor de zorg van haar vier kinderen daar. Met wat ze financieel overhield, had Paquita onvoldoende om te zorgen voor zichzelf en haar dochter in Antwerpen. De onzichtbare 'publieke' arbeid van de vrouwen in dit onderzoek wordt in grote mate ingezet voor de zorg- en huishoudtaken van anderen in een geprivilegieerde positie of zorgtaken voor de gemeenschap, zoals blijkt uit volgend voorbeeld van Amel ${ }^{6}$ :

Eén van mijn jobs was als poetsvrouw op een lagere school. Ik was aangenomen omdat de directeur van een andere school me had aanbevolen bij de directrice van die lagere school. De dag dat ik begin te werken, herkent die directrice me niet. Kort daarna komt ze me vragen of ik mijn hoofddoek wil afdoen. Ik antwoord haar: 'Ja, is er hier een plaats waar ik me kan omkleden?' maar zij antwoordt me: 'Neen, ik wil dat je je hoofddoek afdoet voor je de school binnenkomt, want ik wil niet dat je hier met een hoofddoek over de speelplaats loopt.'

Vanuit een kruispuntperspectief lijkt het integratiemodel niet alleen door een androcentrische bias gekenmerkt, maar ook op het lijf geschreven van het witte, seculiere individu, behorende tot een tweeverdienersgezin waarvan liefst ook beide ouders binnen de natiestaat geboren zijn. In een post-nationale en multiculturele samenleving wordt het aantal mensen die van dit model afwijken echter steeds groter. Een kruispuntperspectief maakt tevens duidelijk hoe de zorgpraktijken van vrouwen zonder papieren worden ervaren en hoe zij met meervoudige discriminaties worden geconfronteerd; bovenstaand citaat toont hoe Amel niet alleen gediscrimineerd wordt door haar vrouw-zijn en haar irreguliere burgerschapstatuut maar ook door haar religieuze (lees: islam-) identiteit. Daarom moeten vrouwen zoals Paquita, Amel en Ella beroep doen op een lokaal netwerk van solidariteit. Maar ondanks die solidariteit slagen vele van deze vrouwen er niet in zorg en betaalde arbeid te combineren. Zo vertelde Ella me hoe moeilijk het is in deze maatschappij om er als moeder zonder papieren en familie alleen voor te staan, en contrasteert dat met de samenleving waar zij vandaan kwam: 'Bij ons is het leven niet zoals hier [...]. De Afrikaanse familie is groot, niet zoals hier waar je enkel een vader en een moeder hebt en een tweetal kinderen.'

Ella ervoer een groot verschil tussen de solidariteit en netwerken die ze in Vlaanderen kent en die waarmee ze opgroeide in Kameroen. Ze had enkele vrienden in Antwerpen die ze tot haar nieuwe, geconstrueerde 
extended family rekent. Analoog aan haar ervaringen van 'othermothering'7 was het haar wens dat haar zoon zich thuis zou voelen bij het gezin van haar vrienden en dat haar zoon de moeder en de vader van dat gezin ook 'mama' en 'papa' kon noemen. Toch was die solidariteit onvoldoende, want in combinatie met de verschillende onstabiele en onderbetaalde jobs die Ella uitoefende, slaagde ze er niet in om altijd opvang voor haar zoon te vinden. Toen hij vijf werd, werd hij deels opgenomen in een systeem van kangoeroe-zorg, waardoor hij één weekend op twee in een geprivilegieerde familie terecht kwam. Ook Amel was genoodzaakt haar drie zonen voor een bepaalde periode af te staan omdat ze er niet in slaagde vanuit haar positie de nodige zorg te bieden.

Ik was ziek geworden en kon niet meer voor mijn kinderen zorgen. Ik heb ze eerst afgegeven aan een Marokkaanse familie in Antwerpen, die ik via via kende. Nadat ik vernam dat mijn zonen daar geslagen werden, heeft een activiste van een Antwerpse organisatie voor mensen zonder papieren ervoor gezorgd dat zij werden opgevangen en geregulariseerd als niet-begeleide minderjarigen. [...] Ik heb toen alles wat ik kon gedaan om er zo snel mogelijk weer bovenop te geraken en mijn zonen terug bij mij te hebben. Dat is gelukt hamdullah!

Vanuit een irreguliere burgerschapspositie en een alleenstaand ouderschap binnen een postmigratiecontext wordt de zorgtaak complexer, zoals Radoesh $^{8}$ het verwoordde:

Hier ben ik vader en moeder tegelijk [...] Je moet veel tijd aan je kinderen besteden. Weet je, eerst stap je met je kinderen maar vanaf het moment dat ik hier kwam, moest ik met mijn kinderen lopen [...] Ik sliep tussen de zorg van mijn kinderen en mijn jobs maar drie, vier uur per nacht...

Door de meervoudige discriminaties komen vrouwen zonder papieren in een moeilijke en ambivalente positie terecht met betrekking tot integratie. Uit vorig onderzoek (Kershaw 2005; 2010; Lister 2010; Longman, De Graeve \& Brouckaert 2013) blijkt dat moederschap bij etnisch culturele minderheden als burgerschapspraktijk kan worden gezien en hoe de moederschapsidentiteit bij vrouwen zonder papieren (Brouckaert 2014) een potentieel politiek burgerschap voor hen mogelijk maakt, doordat moederschap in sommige contexten net een mogelijkheid tot erkenning en zichtbaarheid biedt. Aldus kunnen hun ervaringen van moederschap in relatie tot de eisen voor de erkenning van hun burgerschap op sommige momenten tegengesteld 
lijken aan de moederschapservaringen van witte vrouwen met papieren, bij wie kinderen vaak hun mogelijkheden tot participatie en zichtbaarheid belemmeren. Kortom, de verhalen van de informanten lieten zien hoe Ruddick's (1989) drieledige analyse van universele zorgtaken, die zich richt op (1) onderhoud, (2) affectieve en intellectuele ontwikkeling, en (3) sociale aanvaarding binnen de maatschappelijk context, enkel adequaat begrepen kan worden vanuit een kruispuntperspectief (Brouckaert \& Longman, 2014). In het verlengde hiervan kunnen we ouderschap begrijpen als het beantwoorden aan noden van kinderen volgens specifieke socio-economische (diploma, inkomen en burgerschapsstatus) en culturele (traditie, subgroep, religie) omstandigheden. Zo kunnen we aannemen dat de uitsluiting van burgerschap de levens van personen zonder papieren op een heel dwingende en beperkende manier conditioneert.

\section{Netwerken als extrajuridische bron}

Sociologisch en etnografisch onderzoek (Stein 1981; Portes, 2000; Leman, Siewiera \& Van Broeck 1994; Leman 1995; Engbersen, Van der Leun, Staring \& Kehla 1999; Adam et al. 2001; Devillé 2006; Paspalanova 2006; Brouckaert 2013) dat betrekking heeft op mensen zonder papieren geeft aan dat een informeel zorgnetwerk op basis van solidariteit soelaas kan brengen in een leven waar recht op basis van burgerschap tekort schiet. De concepten 'sociaal' en 'cultureel kapitaal' worden vaak aangehaald als het gaat over netwerken en solidariteit bij mensen zonder papieren. Zo stelt Leo Chavez (1998, p. 193) in zijn onderzoek naar mensen zonder papieren in de Verenigde Staten dat migranten zonder papieren een netwerk moeten ontwikkelen van vrienden en kennissen van wie ze afhankelijk kunnen zijn, omdat ze niet altijd op andere bronnen kunnen rekenen, zoals een toereikend salaris of toegang tot sociale diensten. Netwerken bij migranten zonder papieren worden vaak begrepen, door de overheid maar ook binnen wetenschappelijk onderzoek, in culturele termen en niet in functionele termen.

Als we vertrekken vanuit een functionele visie op netwerken en vanuit de hypothese dat netwerken werken als extrajuridische bron, dan krijgen we een ander beeld te zien. Enerzijds kunnen mensen zonder papieren aankloppen bij non-gouvernementele organisaties en anderzijds is deze hulp afkomstig van particulieren. In het eerste geval kunnen mensen zonder papieren meestal materiële hulp verwachten zoals voedselpakketten, maaltijden en kledij. Een aantal mensen zonder papieren kunnen ook op deze instanties rekenen voor informatie en bijstand in het vinden van een 
weg in het juridische kluwen om op die wijze aanspraak te kunnen maken op basisrechten. Het gaat om een relatie tussen mensen waarbij begrip en wederzijds respect ontstaat tussen de vrijwilligers of sociaal werkers en de persoon zonder papieren. Bovendien zijn deze sociale interacties ook onderdeel van de extrajuridische bronnen waar mensen zonder papieren beroep op kunnen doen.

Ella's verhaal illustreert dit punt. Na de geboorte van haar zoon kreeg ze een depressie waardoor het onmogelijk werd voor haar om, alleen en zonder papieren, voor hem te zorgen. Hij bracht zijn eerste levensjaar door in een instelling. Nadien, toen het psychologisch beter met haar ging, liet ze haar zoon nog even in de instelling ook al was dat een hele moeilijke beslissing.

Ik kon hem meenemen naar huis zonder in staat te zijn hem zelfs maar eten te geven of ik kon nog zo lang mogelijk werken daarbij verschillende jobs en dubbele shiften combinerend. Ik heb voor dat laatste gekozen. [...] pas op, nu ook nog zijn er dagen dat ik niet voldoende geld heb om eten te kunnen kopen. Dan grijp ik in de 'rosse centjes' die ik oppot voor moeilijke dagen en dan koop ik alleen voor hem wat.

Bij de hulp die ze aanvaardde van organisaties moest Ella goed afwegen wat haar het meest opbracht. Want relaties met sociaal werkers vergen tijd en energie. Zeker voor vrouwen die uitgesloten zijn van civiele en sociale rechten; voor hen betekent dit soms het equivalent van een halftijdse job (Gurstein \& Vilches, 2010). Dit werd duidelijk op de dag dat ik Ella hielp met haar verhuis ${ }^{9}$ en ze langs de sociale organisatie wilde gaan waar ze vaak hulp kreeg met papieren en informatie. Ze wilde 'haar' sociaal werkster een gelukkige verjaardag wensen, omdat Ella 'een goede band' met het personeel van organisaties belangrijk vond. In het gesloten opvangcentrum van Kapellen had ze eveneens een goede band met een sociaal werkster. 'Ze zag mij als haar kleinere zusje en bracht kledij en zelfs een oude gsm voor me mee.' Sociale relaties zijn nooit helemaal functioneel, maar evenmin volledig vrijblijvend; ook in sociale relaties met mensen uit de organisatie moet er een soort engagement en reciprociteit bestaan (Derycke, 2006). Ella wist dat de perceptie van degene die hulp biedt sterk kan variëren naargelang de ingeschatte behoefte, de ingeschatte kans op een legale toekomst (Devillé 2006) of naargelang de sociale relatie anoniem of minder anoniem blijft. Uit onderzoek blijkt dat sociaal werkers moeders met jonge kinderen bevoorrechten of dat ook de rechtmatige toegang tot sociale, materiële en politieke hulp geopend wordt voor ouders, meestal moeders van jonge kinderen (Siméant, 1998; Blin, 2005; Devillé, 2006; Brouckaert, 
2013; Nicholls, 2013). Een vrijwilligerster maakte duidelijk aan Véronique ${ }^{10}$ dat solidariteit gelinkt is aan empathie en ingeschatte behoeften: 'Je hoeft niet bang te zijn. Als jij wordt uitgewezen komt iedereen op straat, ze gaan toch geen moeder met vier kinderen uitwijzen.'

De relaties die vrouwen zonder papieren onderhouden met mensen die wel (een aantal van) de dominante privileges (burgerschapsstatuut, wit, man, seculier, tweeverdiener) bezitten, zijn vaak asymmetrisch (Vandenbroeck et al., 2009). De tweede vorm van netwerken, solidariteit met particulieren, is meestal de vorm die in onderzoek besproken wordt, of waar beleidsmakers op doelen. De vrouwen in deze studie migreerden autonoom naar Vlaanderen, waarbij Vlaanderen meestal geen bewust gekozen plaats is maar eerder het resultaat van een samenloop van omstandigheden of een aaneenschakeling van toevalligheden. Als gevolg hiervan kwamen deze tien vrouwen niet terecht in een bestaand netwerk maar is het netwerk dat ze doorheen de jaren van een leven in illegaliteit opbouwden de vrucht van hun eigen expertise en engagement. Sociale relaties en netwerken opbouwen en onderhouden vraagt een engagement, ze zijn immers nooit gratuit maar ingebed in een ruimere relationele context (Derycke, 2006). In Bolivia was Paquita Anglicaans maar toen ze in Antwerpen kwam, sloot ze zich aan bij de katholieke kerk die op zondag een Spaanstalige dienst had. Op die manier maakte ze kennis met andere Spaanssprekende vrouwen die meestal uit Zuid-Amerika afkomstig waren. Maar ook Michaëla en Maria, twee vrouwen uit Roemenië die enkele jaren transnationaal moederschap achter zich hadden in Spanje, sloten zich op die manier aan bij het netwerk van Paquita en andere Spaanssprekende vrouwen.

Ook al was tijdens de periode van mijn onderzoek een significant deel van de sociale contacten van deze vrouwen met personen die dezelfde nationaliteit, etniciteit of taal deelden, toch zijn de banden, relaties en netwerken gelaagder en dynamischer dan over het algemeen wordt aangenomen. Taal en religie zijn belangrijke factoren van contact, maar de diversiteit en de complexiteit van netwerken en betekenisvolle interacties wordt miskend. Bovendien is de dynamiek in een postmigratiecontext, meer dan waar ook in de maatschappij, doordrongen van intra-etnische divisies, interne hiërarchieën en nieuwe machtsrelaties (Brouckaert, 2013; Erel, 2009).

\section{Conclusie: integratie vanuit een kruispuntperspectief}

Dit artikel heeft de ervaringen weergegeven van vrouwen zonder papieren in hun confrontatie met dominante integratievertogen. Het narratief van 
de natiestaat legt de nadruk op een assimilatie aan een dominante cultuur en culpabiliseert degenen die afwijken van die onzichtbare culturele norm. Echter, nieuwe vormen van solidariteit afbreken op basis van een voorbijgestreefde of onzichtbare norm is geen duurzame oplossing voor de sociale cohesie. Doordat beleidsmakers bepaalde vormen van sociaal engagement niet erkennen, blijven vrouwen zonder papieren niet alleen uitgesloten van basisburgerschapsrechten maar wordt hun informeel sociaal netwerk aangetast en daardoor wordt hun laatste vangnet geraakt. Hiermee komt de overheid in een ambivalente positie terecht. Enerzijds wil ze de sociale cohesie opnieuw stimuleren in tijden waar de door de overheid gecreëerde solidariteit geen stand kan houden en voert ze inclusieve burgerschapsvertogen. Anderzijds bestraft ze nieuwe vormen van solidariteit en sociale cohesie. De erkenning van onzichtbaar werk, solidariteit en sociale cohesie is afwezig in erkenning en regularisatiecriteria. Vormen van solidariteit en sociale cohesie die betekenisvol kunnen zijn in een heropleving van burgerschap in een postnationaal tijdperk blijven onerkend. Etnische identiteiten die aan netwerken worden gekoppeld blijken even fictief te zijn als een burgerschapsidentiteit (Balibar 2013). Tussen criteria van exclusie en inclusie ontstaan hiaten die praktijken van burgerschap ontmoedigen in plaats van stimuleren.

Met dank aan de redactie van het tijdschrift en de anonieme referenten.

\section{Noten}

1. Alle interviews en interacties gebeurden, indien mogelijk, in de taal van de informanten. De voertaal met Paquita was Spaans, met Ella sprak ik Frans, met anderen dan weer Engels of Nederlands. De citaten zijn dus eigen vertalingen.

2. Ella is in Vlaanderen moeder geworden van een zoon die vandaag al 7 jaar oud is.

3. Duurzame lokale verankering valt in de beleidscriteria uiteen in (1) - ononderbroken verblijf van tenminste vijf jaar met hetzij verblijfstitel, hetzij geloofwaardige pogingen vóór 18 maart 2008 om een verblijfstitel te verkrijgen en of (2) - ononderbroken verblijf sinds 31 maart 2007 met sociale, affectieve en economische belangen in België, of de mogelijkheid een arbeidscontract voor te leggen.

4. Paquita komt uit Bolivia, waar ze vier kinderen achterliet die bijna de volwassen leeftijd hebben bereikt. Zijzelf is 46 en woont met haar dochter van vier in Antwerpen, België. In 2009 doet ze voor het eerst een poging om haar verblijf te regulariseren, al woont ze op dat moment al meer dan zes jaar in België. Tijdens haar regularisatie aanvraag heeft Paquita moeite om haar jaren van verblijf in Vlaanderen aan te tonen omdat ze tot dan toe zo anoniem mogelijk heeft geleefd. Doktersbezoeken, huurcontracten en gas-en elektriciteitsfacturen staan allemaal op naam van iemand anders. 
5. Traditioneel wordt het debat rond zorg en erkenning vanuit het normatieve tweeverdienersmodel gevoerd; dan krijgen we vanuit een feministisch debat verschillende posities te horen. Algemeen kan wel worden gesteld dat feministisch onderzoek heeft aangetoond hoe de tweedeling publiek/privé, waarop de meeste theorieën van burgerschap zijn gebaseerd, eigenlijk een model voorstelt dat op de maat van de man is getailleerd. De erkenning van betaald werk en rechten die daarvan worden afgeleid, onderwaarderen of sluiten het werk dat in de privésfeer wordt verricht uit. Niet toevallig wordt het werk in de privésfeer waartoe kinderen opvoeden en huishouden behoren, traditioneel en tot op vandaag voor het grootste deel door vrouwen gedaan (Lister, 2003, p. 336; Brouckaert, 2013, p.28).

6. Amel is een vrouw uit Marokko, die met haar drie kinderen naar België kwam.

7. Othermothering is een vorm van collectief moederschap waarbij kinderen niet noodzakelijk door hun biologische ouder of door juridische verplichting worden opgevoed. Deze praktijk was traditioneel gebruikelijk op sommige plaatsen in Afrika, maar op andere plaatsen in een postmigratiecontext kan een variant van deze praktijk worden aangewend om het hoofd te bieden aan hun situatie als alleenstaande ouder zonder papieren (Hill-Collins, 1994; Brouckaert, 2013).

8. Radoesh, moeder zonder papieren uit Iran, kwam naar Vlaanderen met haar twee kinderen.

9. Op die dag stuurt ze een vriendin in haar plaats naar haar job in de appelpluk.

10. Véronique is heel recent en hoogzwanger in Europa aangekomen, samen met haar drie andere jonge kinderen.

\section{Literatuur}

Adam I., Ben Mohammed N., Kagné B., Martiniello M. \& A. Réa. (2001). Itinéraires de sans-papiers en Belgique. Bruxelles: Fondation Roi Baudouin.

Balibar, E. (2013). Nous, citoyens d'Europe?: Les frontières, l'État, le peuple. Paris: La Découverte.

Blin, T (2005). Ressources, stratégies et régulation d'un espace d'action collective: Le cas des 'réfugiés' de saint-ambroise. L’Année Sociologique, 55(1), 171-196.

Botman, M., N. Jouwe \& G. Wekker (red.) (2001) Caleidoscopische visies:De zwarte, migranten-en vluchtelingen-vrouwenbeweging in Nederland. Amsterdam: Koninklijk Instituut voor de Tropen.

Boyd, M. (1989). Family and personal networks in international migration: Recent developments and new agendas. International Migration Review, 23(3), 638-670.

Brouckaert, T. (2013) Accoucher la citoyennté. Expériences et témoignages de femmes sans-papiers à propos de leur travail maternel (unpublished doctoral thesis)

Brouckaert, T. (2013) Undocumented mothers on the national stage. (ongepubliceerd conferentie paper, gepresenteerd 22 november 2013 aan de Open University London 'Migrant Mothers Caring for the Future') http://www.open.ac.uk/ccig/events/migrant-mothers-caring-forthe-future

Brouckaert, T \& Longman, C. (2014) Social networks and childcare strategies among undocumented migrant mothers. European Journal of Women's Studies (Forthcoming).

Chavez, L. R. (1998). Shadowed lives: Undocumented immigrants in American society. New York: Harcourt Brace College Publishers.

Derycke, M (2006). Des rires de “dominés”, déprise de l'enquêteur. Langage et Société, 3, 9-40.

Devillé, A. (2006). De onzichtbare rechteloze klasse. De leef- en belevingswereld van mensen zonder wettig verblijf in Vlaanderen en Brussel. Tijdschrift voor Sociologie, 2, pp. 131-156. 
Devillé, A. (2008). Schuilen in de schaduw. Mensen zonderwettigverblijf in de Belgische samenleving. Een kwalitatieve 'multi-method' benadering. Mechelen: Wolters Kluwer Belgium NV.

Engbersen, G., Van der Leun, J., Staring, R., \& Kehla, J. (1999). Inbedding en uitsluiting van illegale vreemdelingen [Incorporation and Exclusion of Illegal Immigrants]. Amsterdam: Boom.

Erel, U. (2009). Migrant women transforming citizenship: Life-stories from Britain and Germany. Farnham: Ashgate.

Fortier, A.-M. (2010). Proximity by design? Affective citizenship and the management of unease. Citizenship Studies, 14(1), 17-30.

Gurstein, P., \& Vilches, S. (2010). The just city for whom? Re-conceiving active citizenship for lone mothers in Canada. Gender, Place and Culture, 17(4), 421-436.

Kershaw, P. (2005). Carefair: Rethinking the responsabilities and rights of citizenship. Vancouver: UBC Press.

Kershaw, P. (2010). Caregiving for identity is political: Implications for citizenship theory. Citizenship Studies, 14(4), 395-410.

Leman, J. (1995). Sans document: Les immigrés de l'ombre. Latino-américains, polonais et nigérians clandestins. Brussel: De Boeck \& Larcies s.a.

Leman, J., Siewiera, B., \& Van Broeck, A. (1994). Documentloze immigranten te Brussel. Brussel: Cultuur en Migratie vzw.

Lister, R. (2003). Citizenship: feminist perspectives. New York: NYU Press.

Lister, R. (2010). Response. Women's Studies Quartely, 38(1-2), 318-323.

Longman, C., K. De Graeve, \& T. Brouckaert (2013). Mothering as citizenship practice: An intersectional analysis of 'carework' and 'culturework'in non-normative mother-child identities. Citizenship Studies, 17(3-4), 385-399.

Lykke, N. (2010). Feminist studies: A guide to intersectional theory, methodology and writing. Routledge: London.

McDowell, T., \& Fang Shi-Ruei, S. (2007). Feminist-informed critical multiculturalism: Considerations for family research. Journal of Family issues, 28(4), 549-566.

Nicholls, W.J. (2013). Fragmenting citizenship: Dynamics of cooperation and conflict in France's immigrant rights movement. Ethnic and Racial Studies, 36(4), 611-631.

Paspalanova, M. (2006). Undocumented and legal Eastern European immigrants in Brussels (doctoral dissertation). Retrieved from https://lirias.kuleuven.be/handle/1979/432

Portes, A. (2000). Social capital: Its origins and applications in modern sociology. In: Lesser, E. Knowledge and Social Capital (pp. 43-67). Boston: Butterworth-Heinemann.

Putnam, R. D. (2000). Bowling alone: The collapse and revival of American community. New York: Simon and Schuster.

Ruddick, S. (1989). Maternal thinking: Towards a politics of peace (2ed.). Boston: Beacon Press.

Yuval-Davis, N. (2006). Intersectionality and feminist politics. European Journal of Women's Studies, 13(3), 193-209. Siméant, J. (1998). La cause des sans-papiers. Paris: Presses de Sciences po.

Stein, B. N. (1981). Understanding the refugee experience: Foundations of a better resettlement system. Journal of Refugee Resettlement, 1(4), 62-71.

Vandenbroeck, M., Roets, G., \& Snoeck, A. (2009). Immigrant mothers crossing borders: Nomadic identities and multiple belongings in early childhood education. European Early Childhood Education Research Journal, 17(2), 203-216. 


\section{About the author}

Dr Tine Brouckaert holds a PhD in Comparative Sciences of Culture at Ghent University and the University of Saint-Etienne. Her dissertation "Giving birth to citizenship" (original: "Accoucher la citoyenneté. Expériences et témoignages de femmes sans-papiers à propos de leur travail maternel") addresses questions on mothering with an undocumented citizenship status. Her research interests are critical citizenship, feminist and postcolonial studies, anthropology of gender and diversity, ethnotheatre and gender practices in recruitment and selection in university policy.

E-mail: Tine.Brouckaert@ugent.be

Bent u blij met dit exemplaar van het Tijdschrift voor Genderstudies? Zo ja, misschien zou u ons kunnen steunen met een fiscaal aftrekbare gift, dan kunnen wij dit soort mooie nummers blijven maken!

Zie voor meer informatie www.tijdschriftvoorgenderstudies.nl. Zie daar: Become a friend of the journal/donateurs. 